\title{
Demineralization of Gondwana coal with Pseudomonas mendocina strain B6-1: a case study of coal from Gopinathpur top and bottom seams of Mugma mine, Dhanbad, Jharkhand (India)
}

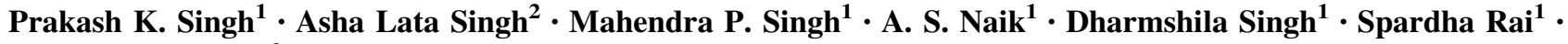 \\ Aniruddha Kumar ${ }^{2}$
}

Received: 24 October 2015/Revised: 20 December 2015/Accepted: 23 February 2016/Published online: 17 June 2016

(C) The Author(s) 2016. This article is published with open access at Springerlink.com

\begin{abstract}
In the present investigation an attempt has been made to demineralize the Gondwana coal of Gopinathpur top and bottom seams of Mugma mine, Raniganj coalfield, Dhanbad with the help of Pseudomonas mendocina strain B6-1. The change in the amount of ash yield and decrease in the concentration of selected minor elements like $\mathrm{Na}, \mathrm{K}, \mathrm{Mn}$ and $\mathrm{Ca}$ and environmentally sensitive selected trace elements such as $\mathrm{Cd}, \mathrm{Pb}, \mathrm{Se}, \mathrm{Ni}, \mathrm{Mn}$, and $\mathrm{Zn}$ have been studied as a function of time of bacterial treatment as well as with variation in the bacterial biomass. After 28 days of bacterial treatment there was variable amount of decrease observed in ash yield as well as in the concentration of minor and trace elements. The removal of the elements was further enhanced with the increase in the bacterial biomass from 10 to $25 \mathrm{mg} / \mathrm{mL}$. Due to over exploitation of superior grade coals in the country, the remaining coal resources, available for current use, are inferior in grade and contain high level of impurities and there is ample scope of bio-beneficiation of these coals using bacterial biomass.
\end{abstract}

Keywords Pseudomonas mendocina $\cdot$ Gondwana coal · Minor and trace elements · Demineralization

\section{Introduction}

Coal is an important source of energy and is mainly used to generate electricity in the thermal power plants. Gondwana coals of India contribute more than $99 \%$ of total coal resource of the country and are with medium to high ash yield. Due to over exploitation of superior grade coals, the remaining resources are inferior in grade having high level of impurities. Moreover, the Gondwana coals being of drift origin contain relatively high inorganic matter. These inorganic matters get associated with coal during various stages and have different modes of occurrences such as (a) dissolved salts and other inorganic substances in the

Prakash K. Singh

prakashbhu@rediffmail.com

1 Coal \& Organic Petrology Lab, Centre of Advanced Study in Geology, Banaras Hindu University, Varanasi 221005, India

2 Bioremediation Lab, Environmental Science, Department of Botany, Banaras Hindu University, Varanasi 221005, India pore water of coal, (b) inorganic elements which are incorporated within the organic compounds of macerals, and (c) crystalline or non-crystalline discrete inorganic particles representing actual mineral components. During mining activities the minerals derived from the non-coal bands from intra-seam further add to the impurities. Removal of those inorganic matters which are chemically bonded with the organic matter is difficult through physical cleaning and has become a matter of concern for the scientists. Besides, there are several elements which occur in association of organic and inorganic constituents as major $(>1 \mathrm{wt} \%)$, minor $(1-0.1 \mathrm{wt} \%)$ or trace $(<0.1 \mathrm{wt} \%)$ elements (Vassilev and Vassileva 1997). The elements like As, $\mathrm{Be}, \mathrm{Cd}, \mathrm{Cr}, \mathrm{Cu}, \mathrm{Pb}, \mathrm{Mn}, \mathrm{Hg}, \mathrm{Mo}, \mathrm{Ni}, \mathrm{Sr}, \mathrm{U}, \mathrm{V}$, and $\mathrm{Zn}$ are considered to be environmentally sensitive (Pickhardt 1989). Significant contributions on the geochemistry of trace elements have been made by several scientists (Finkelman 1995; Ward et al. 2003; Ren et al. 2004; Seredin 2004; Eskenazy 2009; Zhao et al. 2014; Singh et al. $2015 a, b)$. Geochemistry of trace elements of Indian coals has been studied by Singh et al. (1983, 2015a) and Prachiti 
et al. (2011). Since studies on the demineralization of coal using bacterial biomass have not been carried out in details, there is much scope of such investigations. Contributions on limited numbers of coal samples have been made by Singh et al. (2012, 2014a, b, 2015c).

In the present investigation an attempt has been made to demineralize the Gondwana coal of Gopinathpur seam from Raniganj coalfield with the help of Pseudomonas mendocina strain B6-1. The change in the amount of the ash yield and change in the concentration of environmentally sensitive selected trace elements have been studied as a function of time of bacterial treatment as well as with variation in the bacterial biomass.

\section{Methods of study}

The coal samples for present investigation were collected from the Gopinathpur top and bottom seams of Mugma mine, Nirsa block. These Gondwana coals belong to Barakar Formation of Raniganj coalfield, Dhanbad district, Jharkhand. Two coal samples from Gopinathpur bottom seam (GB-1and GB-2) and one sample from Gopinathpur top seam (GT-1) have been subjected to bacterial treatment and various analyses.

\subsection{Coal petrography}

The maceral analysis has been carried out under Leitz Orthoplan Pol Microscope in Coal \& Organic Petrology Lab, Banaras Hindu University. Oil recommended by Leitz (DIN 58889) has been used for the microscopy. The lineto-line and point-to-point spacings were maintained at $0.4 \mathrm{~mm}$ and more than 500 counts were taken on each sample. The methodology and recommendations given by Taylor et al. (1998) and ICCP (2001) were followed.

\subsection{Proximate analysis}

The proximate analysis has been carried out as per ISI specifications (BIS 2003) to determine the contents of moisture, ash, volatile matter and fixed carbon. The analysis was carried out in Coal \& Organic Petrology Lab, Banaras Hindu University.

\subsection{Minor and trace element analysis}

One gram (dry weight) of Gopinathpur seam coal sample was transferred in a digestion vessel and $10 \mathrm{~mL}$ of digestion mixture (10 part conc. $\mathrm{HNO}_{3}$ and 1 part $\mathrm{HClO}_{4}$ ) was added to it. The mixture was refluxed for $30 \mathrm{~min}$ and the step was repeated thrice so that no brown fumes were given off by the sample. It was filtered using Whatman (No. 41) filter paper. The digested samples were rinsed with $1 \%$ Conc. $\mathrm{HNO}_{3}$ and transferred in a separate test tube. The volume was made up to $20 \mathrm{~mL}$. Concentrations of $\mathrm{Cd}, \mathrm{Pb}$, $\mathrm{Se}, \mathrm{Ni}, \mathrm{Mn}$, and $\mathrm{Zn}$ elements were determined using Perkin-Elmer Inductively Coupled Plasma optical emission spectrometer (ICP-OES), model Optima 7000 DV, in the School of Life Sciences, Banaras Hindu University. Concentrations of other elements like $\mathrm{Na}, \mathrm{K}$ and $\mathrm{Ca}$ were determined using Systronics Flame Photometer 128 in the Department of Botany, Banaras Hindu University.

\subsection{Bacterial treatment}

\subsubsection{Isolation and identification of bacteria}

The bacteria used in the present investigation were isolated from Rajmahal coals and the detailed process has been discussed by Singh et al. (2014a, b). Identification of bacteria was carried out at Indian Institute of Vegetable Research (IIVR), Varanasi (Singh et al. 2014a, b). The bacterium was identified as $P$. mendocina strain B6-1.

\subsubsection{Mass cultivation of Pseudomonas mendocina strain B6-1 bacteria}

The isolated bacterial colonies have been grown in a growth medium and the growth of the colonies was measured individually at $660 \mathrm{~nm}$ with the help of spectrophotometer. The colony with maximum growth has been picked up, purified and transferred into liquid basal salt medium for mass cultivation. The medium had a composition of: glycerol $0.2 \%, \mathrm{KH}_{2} \mathrm{PO}_{4} 0.244 \%, \mathrm{NaHPO}_{4}$ $0.577 \%, \mathrm{NH}_{4} \mathrm{Cl} 0.2 \%$ and $\mathrm{MgCl}_{2} 0.02 \%$.

\subsubsection{Immobilization of Pseudomonas mendocina strain B6-1 bacteria}

The exponential phase bacterial cells have been collected through centrifugation at $10000 \mathrm{rpm}$ for $10 \mathrm{~min}$ and repeated washing. The final pellet was collected for further use. Mixture of $5 \%$ sodium alginate solution was poured into broth of basal salt medium and was sterilized. Bacterial beads were prepared by adding $10 \mathrm{mg} / \mathrm{mL}$ of bacterial biomass into sodium alginate solution and this mixture was pumped drop wise into $0.2 \mathrm{M} \mathrm{CaCl}_{2}$ solution in sterilized condition under laminar flow. The bacterial beads thus prepared were harvested and resuspended in $100 \mathrm{~mL}$ growth medium in elementary flask of $250 \mathrm{~mL}$. The same method was adopted for the preparation of bacterial beads using $25 \mathrm{mg} / \mathrm{mL}$ biomass. 


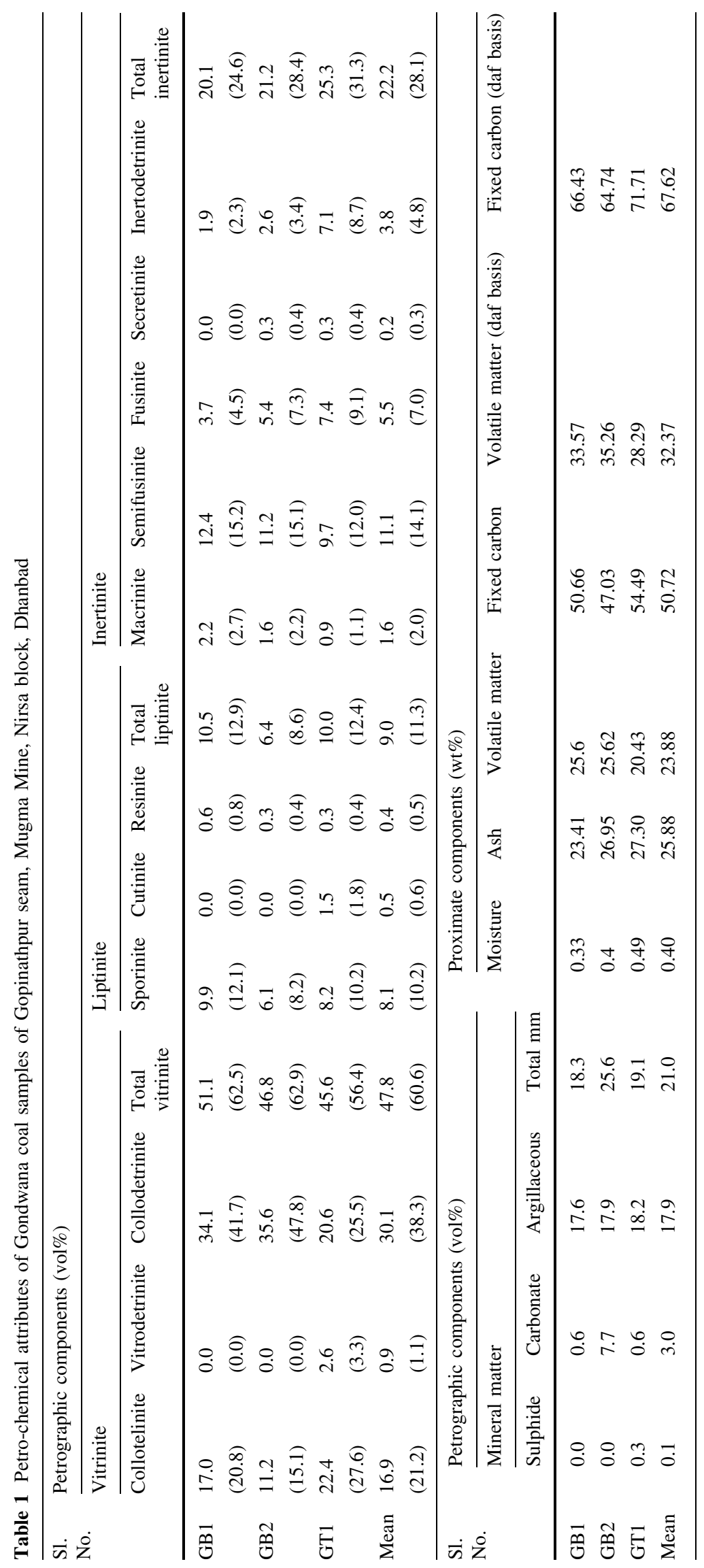




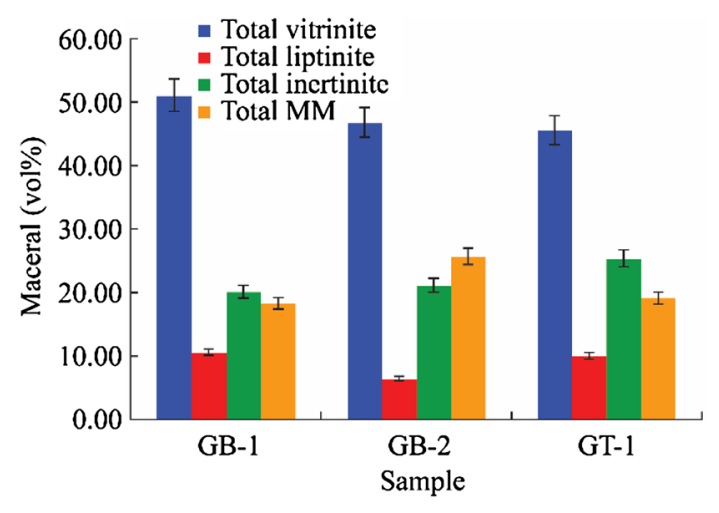

Fig. 1 Petrographic composition of Gopinathpur coal samples

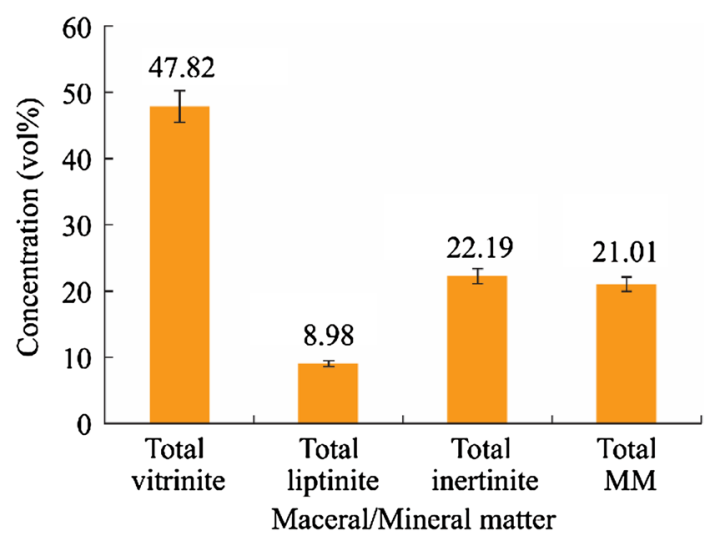

Fig. 2 Mean values of petrographic elements (vol\%) in Gopinathpur coal

\subsubsection{Method of treatment}

Demineralization of coal samples of Gopinathpur seam was carried out with $P$. mendocina strian B6-1. These coal samples have been crushed to 70 mesh size. Two sets of coal samples (about $12 \mathrm{~g}$ ) were taken (one for control and the other for treatment) in $50 \mathrm{~mL}$ basal salt medium and the $\mathrm{pH}$ was adjusted at five which was maintained with the help of $1 \mathrm{~N} \mathrm{HCl}$. The experiment was performed at room temperature in Erlenmeyer flasks of $100 \mathrm{~mL}$, with volume of $50 \mathrm{~mL}$ basal salt medium. Each coal sample was inoculated with 100 number of bacterial beads of $P$. mendocina strian B6-1 and all the treated samples had a respective control (Blank), i.e. an assay with the same operation conditions but without inoculation. The experiments have been performed with coal samples of Gopinathpur seam of Mugma mine. The treated samples of every $2 \mathrm{nd}, 4 \mathrm{th}, 8 \mathrm{th}$, 12 th, 16th, 20th, 24th, and 28th day were taken out for the analysis. The $\mathrm{pH}$ and oxidation reduction potential (ORP) were monitored throughout the experiment. The solid fraction obtained after filtering it with Whatman filter paper was dried at room temperature and subjected to proximate analysis.

\section{Results and discussion}

\subsection{Petro-chemical attributes}

Gopinathpur coals are dominated by vitrinite group of macerals (45.6\%-51.1\%; 56.4\%-62.9\% mmf basis) which is contributed mainly by collodetrinite and little by collotelinite and vitrodetrinite. Inertinite $(20.1 \%-25.3 \%$; $24.6 \%-31.3 \% \mathrm{mmf}$ basis) and liptinite $(6.4 \%-10.5 \%$; $8.6 \%-12.9 \%$ mmf basis) occur in low concentrations. Inertinite comprises of semifusinite, fusinite, macrinite and inertodetrinite while liptinite comprises of sporinite, resinite and cutinite in these coals. Mineral matter occurs in moderately high concentration (18.3\%-25.6\%) which comprises mainly of clay minerals while carbonates and sulphides occur in low concentration. The details of the petrographic composition of Gopinathpur coals are

Table 2 Selected minor and trace elements investigated in coal samples of Gopinathpur top and bottom seams (ppm)

\begin{tabular}{|c|c|c|c|c|c|}
\hline Element & World average/Clarke value & GB-1 & GB-2 & GT-1 & Mean \\
\hline $\mathrm{Ca}^{\mathrm{a}}$ & 10000 & 918.2 & 1191.5 & 1721.0 & 1276.9 \\
\hline $\mathrm{K}^{\mathrm{a}}$ & 100 & 1189.5 & 1189.5 & 5573.0 & 2650.7 \\
\hline $\mathrm{Na}^{\mathrm{a}}$ & 200 & 5792.0 & 5618.0 & 4534.0 & 5314.7 \\
\hline $\mathrm{Cd}^{\mathrm{b}}$ & $0.2 \pm 0.04$ & $\mathrm{Nd}$ & 1.8 & $\mathrm{Nd}$ & 1.8 \\
\hline $\mathrm{Pb}^{\mathrm{b}}$ & $9 \pm 0.7$ & 13.2 & 1.8 & 9.80 & 8.3 \\
\hline $\mathrm{Se}^{\mathrm{b}}$ & $1.6 \pm 0.1$ & 6.80 & 9.0 & $\mathrm{Nd}$ & 7.9 \\
\hline $\mathrm{Ni}^{\mathrm{b}}$ & $17 \pm 1$ & 18.50 & 8.2 & 32.0 & 19.6 \\
\hline $\mathrm{Mn}^{\mathrm{b}}$ & $71 \pm 5$ & 19.10 & 24.0 & $\mathrm{Nd}$ & 21.5 \\
\hline $\mathrm{Zn}^{\mathrm{b}}$ & $28 \pm 2$ & 9.00 & 13.3 & 31.0 & 17.8 \\
\hline
\end{tabular}

$N d$ not determined

a World average (After Valković 1983)

${ }^{b}$ Coal Clarke values for bituminous coal (Ketris and Yudovich 2009) 
Table 3 Variation in the ash yield and ash reduction of coal samples of Gopinathpur bottom seam analyzed before and after bacterial treatment with $10 \mathrm{mg} / \mathrm{mL}$ biomass

\begin{tabular}{lllll}
\hline Day & Ash yield (wt\%) (GB-1) & Ash reduction $(\%)$ & Ash yield (wt\%) $(\mathrm{GB}-2)$ & Ash reduction $(\%)$ \\
\hline IC & 23.41 & - & 26.95 & - \\
After 2nd day & 23.38 & 0.13 & 26.46 & 1.82 \\
After 4th day & 23.09 & 1.37 & 26.25 & 2.60 \\
After 8th day & 23.07 & 1.45 & 25.83 & 4.16 \\
After 12th day & 23.04 & 1.58 & 25.72 & 4.56 \\
After 16th day & 22.96 & 1.92 & 25.67 & 4.75 \\
After 20th day & 22.91 & 2.14 & 25.64 & 4.86 \\
After 24th day & 22.77 & 2.73 & 25.30 & 6.12 \\
After 28th day & 22.68 & 3.12 & 24.98 & 7.31 \\
\hline
\end{tabular}

IC initial concentration
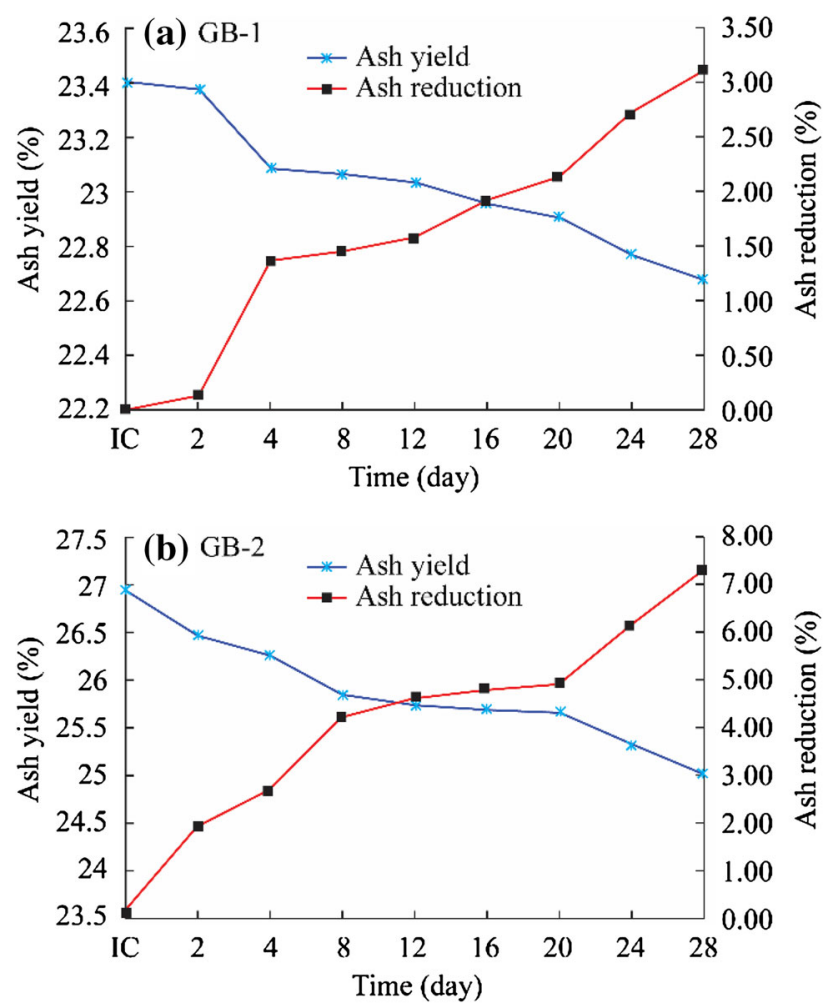

Fig. 3 Variation in the ash yield and ash removal in coal samples of Gopinathpur bottom seam (before and after bacterial treatment using $10 \mathrm{mg} / \mathrm{mL}$ biomass)

furnished in Table 1 while the graphical representation of the group maceral and mineral matter is provided in Fig. 1. The mean values of the petrographic elements are shown in Fig. 2. Gopinathpur seam coals are low in moisture content $(0.33 \%-0.49 \%$; av $0.40 \%)$ but the ash yield of these coals is moderately high and varies from $23.41 \%$ to $27.3 \%$. The volatile matter (daf basis) varies from
$28.29 \%$ to $35.26 \%$ and fixed carbon (daf basis) varies from $64.74 \%$ to $71.71 \%$ (Table 1).

\subsection{Distribution of minor and trace elements}

Gopinathpur seam coals have high concentrations of K (1189.5-5573 ppm; av $2650.7 \mathrm{ppm})$ and $\mathrm{Na}$ (4534-5618 ppm; av $5314.7 \mathrm{ppm}$ ) among the minor elements as compared to the world average in coals as given by Valkovic (1983). Similarly Se (6.8-9.0 ppm; $7.9 \mathrm{ppm})$ and $\mathrm{Pb}(1.8-13.2 \mathrm{ppm}$; av $9.3 \mathrm{ppm})$ are high in concentrations in these coals when compared with the Clarke values of the elements in Bituminous coals as given by Ketries and Yudovich (2009). Other elements analysed in these coals such as $\mathrm{Ni}(8.2-32.0 \mathrm{ppm} ; 19.6 \mathrm{ppm}), \mathrm{Zn}$ (9-31 ppm; av $17.8 \mathrm{ppm})$ and $\mathrm{Mn}$ (19.1-24 ppm; av $21.5 \mathrm{ppm}$ ) occur within the limits. The details of the concentrations of the analyzed minor and trace elements are furnished in Table 2.

\subsection{Demineralization using Pseudomonas mendocina strain B6-1}

Metal removal from coal by bacteria occurs through leaching, adsorption and accumulation. Leaching mechanisms of metals through bacteria takes place in various ways such as, (i) the formation of organic or inorganic acids (protons); (ii) oxidation and reduction reactions; and (iii) the excretion of complexing agents (Berthelin 1983). The chief inorganic acid in leaching environments is sulphuric acid which is formed by sulfur-oxidizing microorganisms. However, a series of organic acids are produced by bacterial metabolism which leads to organic acidolysis, complex and chelate formation and facilitates metal removal (Berthelin 1983). After liberation of metals from coal or organic matter through microbial leaching, the processes like adsorption and 
Table 4 Variation in the ash yield and ash reduction of coal samples of Gopinathpur top seam (GT-1) analyzed before and after bacteria treatment (with 10 and $25 \mathrm{mg}$ biomass of bacteria)

\begin{tabular}{lllll}
\hline Day & $\begin{array}{l}\text { Ash yield (wt\%) (GT-1) } \\
\text { treated with } 10 \mathrm{mg} / \mathrm{mL} \\
\text { biomass }\end{array}$ & $\begin{array}{l}\text { Ash reduction }(\%)(\mathrm{GT}-1) \\
\text { by } 10 \mathrm{mg} / \mathrm{mL} \text { biomass }\end{array}$ & $\begin{array}{l}\text { Ash yield (wt\%) (GT-1) } \\
\text { treated with 25 mg/mL } \\
\text { biomass }\end{array}$ & $\begin{array}{l}\text { Ash reduction }(\%)(\mathrm{GT}-1) \\
\text { treated with 25 mg/mL } \\
\text { biomass }\end{array}$ \\
\hline IC & 27.3 & - & 27.30 & - \\
After 2nd day & 26.2 & 4.03 & 25.51 & 6.56 \\
After 4th day & 25.3 & 7.33 & 23.30 & 14.65 \\
After 8th day & 24.21 & 11.32 & 21.12 & 22.64 \\
After 12th day & 22.9 & 16.12 & 19.59 & 28.24 \\
After 16th day & 22.1 & 19.05 & 18.12 & 33.63 \\
After 20th day & 20.12 & 26.30 & 17.97 & 34.18 \\
After 24th day & 18.45 & 32.42 & 17.42 & 36.19 \\
After 28th day & 18.02 & 33.99 & 17.08 & 37.44 \\
\hline
\end{tabular}

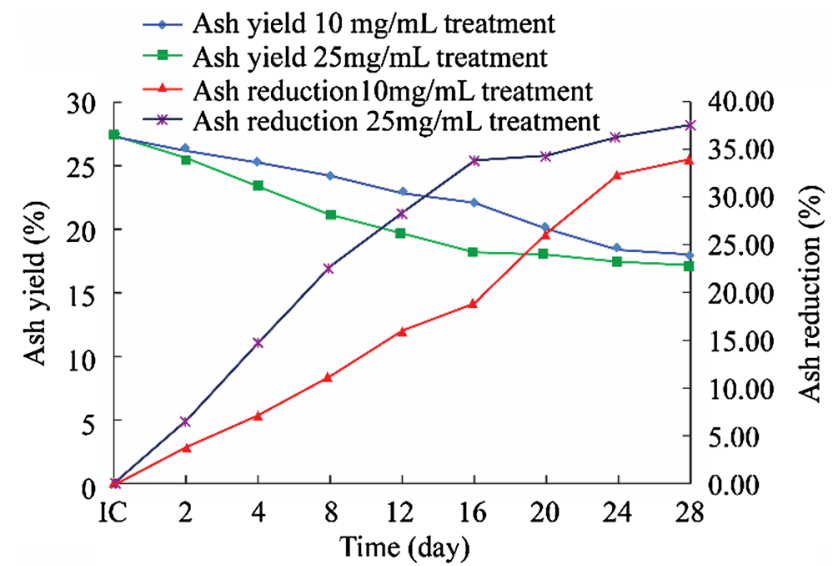

Fig. 4 Variation in ash yield and ash reduction after treatment of GT1 sample by $P$. mendocina strain B6-1 at two biomasses (10 and $25 \mathrm{mg} / \mathrm{mL}$ ) accumulation of metals by bacteria becomes pronounced. The metal binding in adsorption occurs on the bacterial surface. This may occur on the surface of both living as well as non-living bacteria. Numerous negatively charged groups are present on the bacterial cell surface where the positively charged cations bind with them through electrical attraction. Subsequently, the cations are removed. Metal accumulation, in bacteria, refers to translocation of the cations which is a metabolic dependent process and takes place across the wall and membrane into the cell. There is specific transport system for metal ions which involves channels and pores of cell membrane. Polyphosphate body in bacteria works as metal sink (Gadd 2009; Kornberg 1995).

In the present investigation three coal samples, two from Gopinathpur bottom seam (GB-1 and GB-2) and one sample from Gopinathpur top seam (GT-1), have been subjected to demineralization to see decrease in the content

Table 5 Variation in concentration of minor and trace elements in sample GB-1, before and after treatment with $10 \mathrm{mg} / \mathrm{mL}$ of bacterial biomass (ppm)

\begin{tabular}{lrrrrrrrrr}
\hline Element & IC & $\begin{array}{l}\text { After 2nd } \\
\text { day }\end{array}$ & $\begin{array}{l}\text { After 4th } \\
\text { day }\end{array}$ & $\begin{array}{l}\text { After 8th } \\
\text { day }\end{array}$ & $\begin{array}{l}\text { After 12th } \\
\text { day }\end{array}$ & $\begin{array}{l}\text { After 16th } \\
\text { day }\end{array}$ & $\begin{array}{l}\text { After 20th } \\
\text { day }\end{array}$ & $\begin{array}{l}\text { After 24th } \\
\text { day }\end{array}$ & $\begin{array}{l}\text { After 28th } \\
\text { day }\end{array}$ \\
\hline $\mathrm{Ca}$ & 918.2 & 899.9 & 859.4 & 843.4 & 822.0 & 800.6 & 789.8 & 782.6 & 778.2 \\
$\mathrm{~K}$ & 1189.5 & 1189.5 & 1169.8 & 1163.1 & 1144.45 & 1125.9 & 1094.1 & 934.6 & 926.6 \\
$\mathrm{Na}$ & 5792.0 & 4987.0 & 4934.0 & 4822.0 & 4789.0 & 3928.0 & 3072.0 & 2410.0 & 2134.0 \\
$\mathrm{~Pb}$ & 13.2 & 12.1 & 11.5 & 11.5 & 9.1 & 8.7 & 8.2 & 8.0 & 7.7 \\
$\mathrm{Se}$ & 6.80 & 6.40 & 5.80 & 5.78 & 5.50 & 5.20 & 4.30 & 3.20 \\
$\mathrm{Ni}$ & 18.50 & 16.70 & 14.30 & 12.00 & 10.70 & 10.40 & 9.50 & 7.20 \\
$\mathrm{Mn}$ & 19.10 & 15.80 & 18.40 & 14.60 & 14.30 & 6.70 & 4.90 & 5.80 & 6.90 \\
$\mathrm{Zn}$ & 9.00 & 6.80 & 6.40 & 6.00 & 5.10 & 4.40 & 3.00 & 2.70 & 2.60 \\
\hline
\end{tabular}

IC initial concentration 
Table 6 Removal (\%) of minor and trace elements after treatment of sample GB-1 by P. mendocina strain B6-1 with $10 \mathrm{mg} / \mathrm{mL}$ biomass

\begin{tabular}{lrrrrrrrr}
\hline Day & $\mathrm{Ca}$ & $\mathrm{K}$ & $\mathrm{Na}$ & $\mathrm{Mn}$ & $\mathrm{Pb}$ & $\mathrm{Se}$ & $\mathrm{Ni}$ \\
\hline 2 day & 1.99 & 0.00 & 13.90 & 17.28 & 8.33 & 5.88 & 9.73 \\
4 day & 6.40 & 1.66 & 14.81 & 3.66 & 12.88 & 14.71 & 22.70 \\
8 day & 8.15 & 2.22 & 16.75 & 23.56 & 12.88 & 15.00 & 35.14 & 33.33 \\
12 day & 10.48 & 3.79 & 17.32 & 25.13 & 31.06 & 19.12 & 42.16 \\
16 day & 12.81 & 5.35 & 32.18 & 64.92 & 34.09 & 23.53 & 43.78 \\
20 day & 13.98 & 8.02 & 46.96 & 74.35 & 37.88 & 36.76 & 48.65 \\
24 day & 14.77 & 21.43 & 58.39 & 69.63 & 39.39 & 52.94 & 61.08 \\
28 day & 15.25 & 22.10 & 63.16 & 86.39 & 41.67 & 67.65 & 62.70 \\
\hline
\end{tabular}

Table 7 Variation in concentration of minor and trace elements in sample GB-2, before and after treatment with $10 \mathrm{mg} / \mathrm{mL}$ of bacterial biomass (ppm)

\begin{tabular}{lrccccccccc}
\hline Element & IC & $\begin{array}{l}\text { After 2nd } \\
\text { day }\end{array}$ & $\begin{array}{l}\text { After 4th } \\
\text { day }\end{array}$ & $\begin{array}{l}\text { After 8th } \\
\text { day }\end{array}$ & $\begin{array}{l}\text { After 12th } \\
\text { day }\end{array}$ & $\begin{array}{l}\text { After 16th } \\
\text { day }\end{array}$ & $\begin{array}{l}\text { After 20th } \\
\text { day }\end{array}$ & $\begin{array}{l}\text { After 24th } \\
\text { day }\end{array}$ & $\begin{array}{l}\text { After 28th } \\
\text { day }\end{array}$ \\
\hline $\mathrm{Ca}$ & 1191.5 & 972.5 & 886.4 & 859.9 & 845.0 & 830.4 & 803.3 & 799.8 \\
$\mathrm{~K}$ & 1189.5 & 1189.5 & 1169.8 & 1149.1 & 1134.5 & 1128.9 & 1109.0 & 1032.00 & 788.1 \\
$\mathrm{Na}$ & 5618.0 & 4107.0 & 4098.0 & 3940.0 & 3898.0 & 3852.0 & 3501.0 & 2608.0 & 1769.8 \\
$\mathrm{Cd}$ & 1.8 & 1.69 & 1.60 & 1.8 & 1.53 & 1.50 & 1.40 & 1.3 & 1.2 \\
$\mathrm{~Pb}$ & 9.0 & 8.80 & 8.60 & 8.2 & 8.0 & 7.8 & 7.5 & 7.2 & 6.8 \\
$\mathrm{Se}$ & 8.2 & 7.4 & 7.2 & 6.8 & 5.1 & 4.2 & 2.4 & 1.5 & 0.3 \\
$\mathrm{Ni}$ & 24.0 & 17.7 & 17.4 & 17.0 & 16.5 & 16.4 & 15.3 & 12.1 & 9.1 \\
$\mathrm{Mn}$ & 13.3 & 12.8 & 11.5 & 11.2 & 9.9 & 7.7 & 6.4 & 6.2 & 6.2 \\
$\mathrm{Zn}$ & 38.8 & 38.6 & 38.5 & 35.9 & 38.6 & 35.0 & 31.1 & 28.2 & 17.3 \\
\hline
\end{tabular}

Table 8 Removal (\%) of minor and trace elements after treatment of sample GB-2 by $P$. mendocina strain B6-1with biomass $10 \mathrm{mg} / \mathrm{mL}$

\begin{tabular}{llllrrrrrr}
\hline Day & $\mathrm{Ca}$ & $\mathrm{K}$ & $\mathrm{Na}$ & $\mathrm{Cd}$ & $\mathrm{Pb}$ & $\mathrm{Se}$ & $\mathrm{Ni}$ & $\mathrm{Mn}$ & $\mathrm{Zn}$ \\
\hline 2 day & 18.38 & 0.00 & 26.90 & 6.11 & 2.22 & 9.76 & 26.25 & 3.76 & 0.52 \\
4 day & 25.61 & 1.66 & 27.06 & 11.11 & 4.44 & 12.20 & 27.50 & 13.53 & 0.77 \\
8 day & 27.83 & 3.40 & 29.87 & 0.00 & 8.89 & 17.07 & 29.17 & 15.79 & 7.47 \\
12 day & 29.08 & 4.62 & 30.62 & 15.00 & 11.11 & 37.80 & 31.25 & 25.56 & 0.52 \\
16 day & 30.31 & 5.09 & 31.43 & 16.67 & 13.33 & 48.78 & 31.67 & 42.11 & 9.79 \\
20 day & 32.58 & 6.77 & 37.68 & 22.22 & 16.67 & 70.73 & 36.25 & 51.88 & 19.85 \\
24 day & 32.87 & 13.24 & 53.58 & 27.78 & 20.00 & 81.71 & 49.58 & 53.38 & 27.32 \\
28 day & 33.86 & 14.27 & 68.51 & 33.33 & 24.44 & 96.34 & 62.08 & 53.38 & 55.41 \\
\hline
\end{tabular}

of ash yield and the concentrations of minor/trace elements as a function of time (up to 28 days) and change in the concentration of bacterial biomass (10 and $25 \mathrm{mg} / \mathrm{mL}$ ) comprising of $P$. mendocina strain B6-1.

\subsubsection{Decrease in ash yield as a function of time}

Coal samples (GB-1 and GB-2) from Gopinathpur bottom seam have been treated with $10 \mathrm{mg} / \mathrm{mL}$ bacterial biomass of $P$. mendocina B6-1 to see the decrease in the ash yield with time. In case of GB-1 sample there was a gradual decrease in the ash yield and after 28 days of bacterial treatment there was a reduction in the ash yield up to $3.12 \%$. However, in GB-2 coal sample there was relatively more reduction (up to $7.31 \%$ ) in the final ash yield. The details of the periodic reduction in the ash yield are furnished in Table 3 and are graphically shown in Fig. 3. 


\subsubsection{Decrease in ash yield as a function of change in concentration of bacterial biomass}

In this case one coal sample from Gopinathpur top seam (GT-1) was treated with 10 and $25 \mathrm{mg} / \mathrm{mL}$ of $P$. mendocina strain B6-1. In this sample a substantial decrease in the ash yield was noticed. After 28 days of bacterial treatment there was $33.99 \%$ decrease in the ash when $10 \mathrm{mg} / \mathrm{mL}$ of biomass was used while $37.44 \%$ reduction in the ash yield was recorded when $25 \mathrm{mg} / \mathrm{mL}$ of biomass was used. The details of the periodic ash reduction are furnished in Table 4 and are graphically shown in Fig. 4.

\subsubsection{Removal of minor and trace elements as a function of time}

In case of GB-1 coal sample variable removal (\%) of minor elements has been recorded after 28 days of bacterial treatment with $10 \mathrm{mg} / \mathrm{mL}$ of biomass. $\mathrm{Ca}$ and $\mathrm{K}$ have shown a relatively moderate removal of $15.25 \%$ and $22.10 \%$, respectively while $\mathrm{Na}$ and $\mathrm{Mn}$ have shown significantly high removal of $63.16 \%$ and $86.39 \%$, respectively. The trace elements such as $\mathrm{Pb}, \mathrm{Ni}, \mathrm{Se}$ and $\mathrm{Zn}$ have

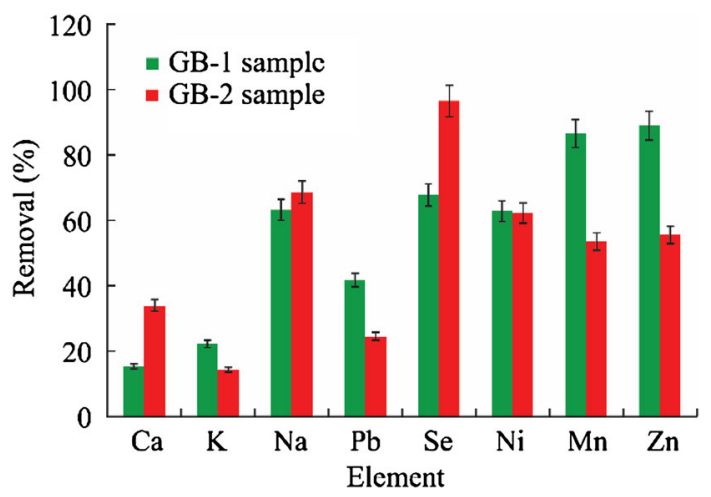

Fig. 5 Comparative removal $(\%)$ of minor and trace elements in GB-1 and GB-2 coal samples, after 28 days of treatment with $P$. mendocina strain B6-1 using $10 \mathrm{mg} / \mathrm{mL}$ biomass shown a high removal of $41.67 \%, 62.70 \%, 67.65 \%$ and $88.89 \%$, respectively in these coals. The decrease in the content of minor and trace elements and their removal percentage are provided in Tables 5 and 6, respectively.

In case of GB-2 coal sample moderately high to very high removal of most of the minor and trace elements has been achieved after 28 days of bacterial treatment. Among the minor elements $\mathrm{K}, \mathrm{Ca}, \mathrm{Mn}$ and $\mathrm{Na}$ have given good response to bacterial treatment and removal was $14.27 \%$, $33.86 \%, 53.38 \%$ and $68.51 \%$, respectively while the trace elements like $\mathrm{Pb}, \mathrm{Cd}, \mathrm{Zn}, \mathrm{Ni}$ and $\mathrm{Se}$ have been removed to a larger extent to the tune of $24.44 \%, 33.33 \%$, $55.41 \%, 62.08 \%$ and $96.34 \%$, respectively. The details of decrease and percent removal are provided in Tables 7 and 8 , respectively. The comparative removal of minor and trace elements in GB-1 and GB-2 coal samples of Gopinathpur bottom seam after 28 days of bacterial treatment using $10 \mathrm{mg} / \mathrm{mL}$ of biomass is shown in Fig. 5 .

\subsubsection{Removal of minor and trace elements as a function of change in the concentration of biomass}

Coal sample (GT-1) from Gopinathpur top seam has been treated with $P$. mendocina B6-1 having 10 and $25 \mathrm{mg} / \mathrm{mL}$

Table 10 Removal (\%) of minor and trace elements after treatment in sample GT-1 by $P$. mendocina strain B6-1 with $10 \mathrm{mg} / \mathrm{mL}$ biomass

\begin{tabular}{lrrrrrr}
\hline Day & \multicolumn{1}{c}{$\mathrm{Ca}$} & \multicolumn{1}{l}{$\mathrm{K}$} & $\mathrm{Na}$ & \multicolumn{1}{c}{$\mathrm{Pb}$} & \multicolumn{1}{c}{$\mathrm{Ni}$} & \multicolumn{1}{c}{$\mathrm{Zn}$} \\
\hline IC & 0.00 & 0.00 & 0.00 & 0.00 & 0.00 & 0.00 \\
2 day & 4.94 & 3.63 & 3.80 & 2.97 & 34.38 & 3.23 \\
4 day & 13.25 & 7.36 & 10.86 & 5.94 & 43.75 & 9.68 \\
8 day & 15.63 & 11.67 & 16.63 & 9.90 & 62.50 & 22.58 \\
12 day & 18.01 & 15.09 & 25.02 & 11.88 & 68.75 & 29.03 \\
16 day & 19.70 & 18.29 & 34.80 & 16.83 & 74.69 & 45.16 \\
20 day & 22.31 & 26.42 & 39.25 & 19.80 & 80.31 & 51.61 \\
24 day & 23.35 & 31.42 & 48.78 & 21.78 & 82.50 & 58.06 \\
28 day & 22.88 & 31.96 & 50.43 & 23.76 & 84.06 & 61.29 \\
\hline
\end{tabular}

Table 9 Variation in concentration of minor and trace elements in sample GT-1, before and after treatment with $10 \mathrm{mg} / \mathrm{mL}$ biomass of $P$. mendocina strain B6-1 (ppm)

\begin{tabular}{llllllllll}
\hline Element & IC & $\begin{array}{l}\text { After 2nd } \\
\text { day }\end{array}$ & $\begin{array}{l}\text { After 4th } \\
\text { day }\end{array}$ & $\begin{array}{l}\text { After 8th } \\
\text { day }\end{array}$ & $\begin{array}{l}\text { After 12th } \\
\text { day }\end{array}$ & $\begin{array}{l}\text { After 16th } \\
\text { day }\end{array}$ & $\begin{array}{l}\text { After 20th } \\
\text { day }\end{array}$ & $\begin{array}{l}\text { After 24th } \\
\text { day }\end{array}$ & $\begin{array}{l}\text { After 28th } \\
\text { day }\end{array}$ \\
\hline $\mathrm{Ca}$ & 1721 & 1636 & 1493 & 1452 & 1411 & 1382 & 1337.1 & 1319.2 \\
$\mathrm{~K}$ & 5573 & 5371 & 5163 & 4923 & 4732 & 4554 & 4101 & 3822 & 1327.3 \\
$\mathrm{Na}$ & 4713 & 4534 & 4201 & 3929 & 3534 & 3073 & 2863 & 2414 & 2379 \\
$\mathrm{~Pb}$ & 10.1 & 9.8 & 9.5 & 9.1 & 8.9 & 8.4 & 8.1 & 7.9 & 7.7 \\
$\mathrm{Ni}$ & 32 & 21 & 18 & 12 & 10 & 8.1 & 6.3 & 5.6 & 13 \\
$\mathrm{Zn}$ & 31 & 30 & 28 & 24 & 22 & 17 & 15 & 12 \\
\hline
\end{tabular}

IC initial concentration 
Table 11 Variation in concentration of minor and trace elements in sample GT-1, before and after treatment of by P. mendocina strain B6-1 with $25 \mathrm{mg} / \mathrm{mL}$ biomass (ppm)

\begin{tabular}{llllllllll}
\hline Element & IC & $\begin{array}{l}\text { After 2nd } \\
\text { day }\end{array}$ & $\begin{array}{l}\text { After 4th } \\
\text { day }\end{array}$ & $\begin{array}{l}\text { After 8th } \\
\text { day }\end{array}$ & $\begin{array}{l}\text { After 12th } \\
\text { day }\end{array}$ & $\begin{array}{l}\text { After 16th } \\
\text { day }\end{array}$ & $\begin{array}{l}\text { After 20th } \\
\text { day }\end{array}$ & $\begin{array}{l}\text { After 24th } \\
\text { day }\end{array}$ & $\begin{array}{l}\text { After 28th } \\
\text { day }\end{array}$ \\
\hline $\mathrm{Ca}$ & 1721 & 1593.3 & 1476.1 & 1423.2 & 1397.5 & 1343 & 1307.3 & 1262.6 & 1233.4 \\
$\mathrm{~K}$ & 5573 & 5079 & 4654 & 4111 & 3545 & 3062 & 2876 & 2754 & 2589 \\
$\mathrm{Na}$ & 4713 & 4331 & 3910 & 3452 & 3012 & 2734 & 2556 & 2359 & 2310 \\
$\mathrm{~Pb}$ & 10.1 & 9.4 & 9.1 & 7.4 & 7.1 & 6.2 & 5.6 & 5.1 & 4.9 \\
$\mathrm{Ni}$ & 32 & 18.1 & 16.3 & 14.3 & 11 & 8.3 & 5.4 & 4.1 & 2.2 \\
$\mathrm{Zn}$ & 31 & 25.1 & 19.2 & 15.1 & 13.2 & 11 & 10 & 9.1 & 4.5 \\
\hline
\end{tabular}

IC initial concentration

Table 12 Removal (\%) of minor and trace elements in sample GT-1, after treatment by $P$. mendocina strain B6-1 with $25 \mathrm{mg} / \mathrm{mL}$ biomass

\begin{tabular}{lrrrrrr}
\hline Day & \multicolumn{1}{c}{$\mathrm{Ca}$} & \multicolumn{1}{l}{$\mathrm{K}$} & \multicolumn{1}{l}{$\mathrm{Na}$} & \multicolumn{1}{l}{$\mathrm{Pb}$} & \multicolumn{1}{c}{$\mathrm{Ni}$} & \multicolumn{1}{c}{$\mathrm{Zn}$} \\
\hline IC & 0.00 & 0.00 & 0.00 & 0.00 & 0.00 & 0.00 \\
2 day & 7.42 & 8.86 & 8.11 & 6.93 & 43.44 & 19.03 \\
4 day & 14.23 & 16.49 & 17.04 & 9.90 & 49.06 & 38.06 \\
8 day & 17.30 & 26.23 & 26.76 & 26.73 & 55.31 & 51.29 \\
12 day & 18.80 & 36.39 & 36.09 & 29.70 & 65.63 & 57.42 \\
16 day & 21.96 & 45.06 & 41.99 & 38.61 & 74.06 & 64.52 \\
20 day & 24.04 & 48.39 & 45.77 & 44.55 & 83.13 & 67.74 \\
24 day & 26.64 & 50.58 & 49.95 & 49.50 & 87.19 & 70.65 \\
28 day & 28.33 & 53.54 & 50.99 & 51.49 & 93.13 & 85.48 \\
\hline
\end{tabular}

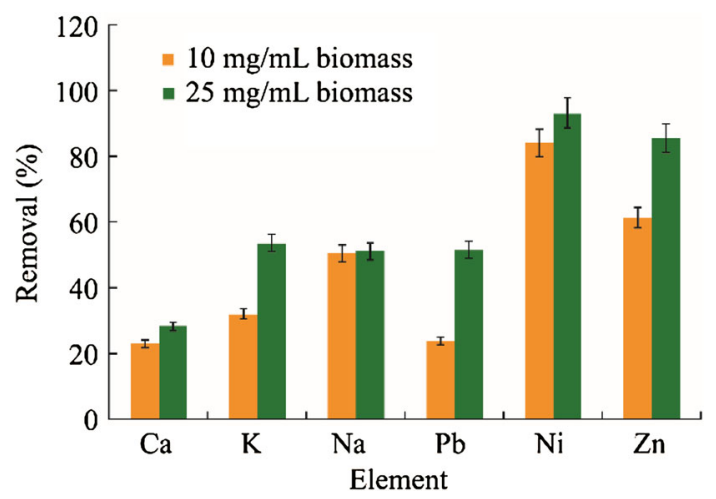

Fig. 6 Comparative removal (\%) of minor and trace elements in GT1 coal sample after 28 days of treatment with $P$. mendocina strain B61 using two biomasses $(10$ and $25 \mathrm{mg} / \mathrm{mL})$

of bacterial biomass to see decrease in the concentration of minor and trace elements and their removal percent. After 28 days of treatment using $10 \mathrm{mg} / \mathrm{mL}$ of biomass, there was moderately high removal. The minor elements such as $\mathrm{Ca}, \mathrm{K}$ and $\mathrm{Na}$ have shown removal of $22.88 \%, 31.96 \%$ and $50.43 \%$, respectively. On the other hand trace elements like $\mathrm{Ni}$ and $\mathrm{Zn}$ have shown a high removal of
$84.06 \%$ and $61.29 \%$, respectively. However, $\mathrm{Pb}$ showed a medium removal of $23.76 \%$. The periodic decrease in the content of elements and their removal percent are provided in Tables 9 and 10, respectively. In case of bacterial treatment using $25 \mathrm{mg} / \mathrm{mL}$ biomass there was significant increase in the removal of elements. $\mathrm{Ca}, \mathrm{K}$ and $\mathrm{Na}$ have shown a removal of $28.33 \%, 53.54 \%$ and $50.99 \%$, respectively after 28 days. Similarly $\mathrm{Ni}, \mathrm{Zn}$ and $\mathrm{Pb}$ have shown a removal of $93.13 \%, 85.48 \%$ and $51.49 \%$, respectively. The periodic decrease in the concentration of these elements and their removal percent are provided in Tables 11 and 12, respectively. The comparative removal (\%) of these elements in GT-1 coal sample of Gopinathpur top seam after 28 days of treatment using 10 and $25 \mathrm{mg} /$ $\mathrm{mL}$ of bacterial biomass is shown in Fig. 6.

\section{Conclusions}

(1) Gopinathpur coals are dominated by vitrinite group of macerals (56.4\%-62.9\% mmf basis) which is contributed mainly by collodetrinite and little by collotelinite and vitrodetrinite. Inertinite $(24.6 \%-$ $31.3 \% \mathrm{mmf}$ basis) and liptinite (8.6\%-12.9\% mmf basis) occur in low concentrations. Mineral matter occurs in moderately high concentration $(18.3 \%-$ $25.6 \%)$.

(2) Gopinathpur seam coals have high concentrations of K (1189.5-5573 ppm) and $\mathrm{Na}$ (4534-5618 ppm) among the minor elements as compared to the world average in coals. Similarly, Se (6.8-9.0 ppm) and $\mathrm{Pb}$ $(1.8-13.2 \mathrm{ppm})$ are high in concentrations when compared with the Clarke values.

(3) Coal samples (GB-1 and GB-2) from Gopinathpur bottom seam have shown a gradual decrease in the ash yield and after 28 days of bacterial treatment there was a reduction in the ash yield up to $3.12 \%$ and $7.31 \%$, respectively. 
(4) Coal sample (GT-1) from Gopinathpur top seam was treated with 10 and $25 \mathrm{mg} / \mathrm{mL}$ of biomass $(P$. mendocina strain B6-1) which indicated a substantial decrease in the ash yield up to $33.99 \%$ and $37.44 \%$, respectively after 28 days.

(5) In coal sample (GB-1) from Gopinathpur bottom, there is $15.25 \%$ and $22.10 \%$ removal of $\mathrm{Ca}$ and $\mathrm{K}$ respectively while $\mathrm{Na}$ and $\mathrm{Mn}$ have shown $63.16 \%$ and $86.39 \%$ removal respectively. The trace elements such as $\mathrm{Pb}, \mathrm{Ni}$, Se and $\mathrm{Zn}$ have shown a high removal of $41.67 \%, 62.70 \%, 67.65 \%$ and $88.89 \%$, respectively. In case of GB-2 coal sample $\mathrm{K}, \mathrm{Ca}, \mathrm{Mn}$ and $\mathrm{Na}$ have given good response to bacterial treatment and removal was $14.27 \%$, $33.86 \%, 53.38 \%$ and $68.51 \%$, respectively while the trace elements like $\mathrm{Pb}, \mathrm{Cd}, \mathrm{Zn}, \mathrm{Ni}$ and $\mathrm{Se}$ have been removed to a larger extent to the tune of $24.44 \%, 33.33 \%, 55.41 \%, 62.08 \%$ and $96.34 \%$, respectively.

(6) When coal sample (GT-1) from Gopinathpur top seam, was treated with $10 \mathrm{mg} / \mathrm{mL}$ of bacterial biomass, the minor elements such as $\mathrm{Ca}, \mathrm{K}$ and $\mathrm{Na}$ have shown removal of $22.88 \%, 31.96 \%$ and $50.43 \%$, respectively and the trace elements like $\mathrm{Ni}$ and $\mathrm{Zn}$ have shown a high removal of $84.06 \%$ and $61.29 \%$, respectively. However, when $25 \mathrm{mg} /$ $\mathrm{mL}$ biomass was used, there was significant increase in the removal of elements. $\mathrm{Ca}, \mathrm{K}$ and $\mathrm{Na}$ have shown a removal of $28.33 \%, 53.54 \%$ and $50.99 \%$, respectively while $\mathrm{Ni}, \mathrm{Zn}$ and $\mathrm{Pb}$ have shown a removal of $93.13 \%, 85.48 \%$ and $51.49 \%$, respectively.

Thus bacteria may be used as an important tool for the beneficiation of coals which are rich in impurities and environmentally sensitive elements. Nevertheless, there is need of more research work in this field to scale-up this experiment on Pilot and commercial levels.

\begin{abstract}
Acknowledgments The authors thankfully acknowledge the Department of Geology and Department of Botany, Banaras Hindu University and Indian Institute of Vegetable Research (IIVR), Varanasi for extending the laboratory and other facilities. The coal samples were collected from the Mugma mine by our students (Ashutosh Singh and Amrita Roy) during 2011-2012. The help rendered by the officials of the Mugma mine is thankfully acknowledged. We are also thankful to the editor for editorial handling of this manuscript.
\end{abstract}

Open Access This article is distributed under the terms of the Creative Commons Attribution 4.0 International License (http://crea tivecommons.org/licenses/by/4.0/), which permits unrestricted use, distribution, and reproduction in any medium, provided you give appropriate credit to the original author(s) and the source, provide a link to the Creative Commons license, and indicate if changes were made.

\section{References}

Berthelin J (1983) Microbial weathering processes. In: Krumbein WE (ed) Microbial geochemistry. Blackwell, Oxford, pp 223-263

BIS (2003) Methods of test for coal and coke (2nd revision of IS: 1350). Part I, proximate analysis. Bureau of Indian Standard, pp 1-29

Eskenazy GM (2009) Trace elements geochemistry of the Dobrudza coal basin, Bulgaria. Int J Coal Geol 78:192-200

Finkelman RB (1995) Modes of occurrence of environmentallysensitive trace elements in coal. In: Swain DJ, Goodarzi F (eds) Environmental aspects of trace elements in coal. Kluwer Academic Publishers, Dordrecht, pp 24-50

Gadd AM (2009) Biosorption: critical review of scientific rationale, environmental importance and significance for pollution treatment. J Chem Technol Biotechnol 84:13-28

ICCP (2001) The new inertinite classification (ICCP system 1994). Fuel 80:459-471

Ketris MP, Yudovich YaE (2009) Estimations of clarkes for carbonaceous biolithes: world averages for trace element contents in black shales and coals. Int J Coal Geol 78:135-148

Kornberg A (1995) Inorganic polyphosphate: toward making a forgotten polymer unforgettable. J Bacteriol 177:491-496

Pickhardt W (1989) Trace elements in minerals of German bituminous coals. Int J Coal Geol 14:137-153

Prachiti PK, Manikyamba C, Singh PK, Balram V, Lakshminarayana G, Raju K, Singh MP, Kalpana S, Arora M (2011) Geochemical systematics and precious metal content of the sedimentary horizons of lower Gondwanas from the Sattupalli coal field, Godavari Valley, India. Int J Coal Geol 88:83-100

Ren D, Xu D, Zhao F (2004) A preliminary study on the enrichment mechanism and occurrence of hazardous trace elements in the Tertiary lignite from the Shenbei coalfield China. Int J Coal Geol 57:187-196

Seredin VV (2004) Au-PGE mineralization in the Pavlovsk subbituminous coal deposit. Primorie Geol Ore Depos 46:43-73

Singh RM, Singh MP, Chandra D (1983) Occurrence, distribution and probable source of the trace elements in Ghugus coals, Wardha Valley, districts Chandrapur and Yeotmal, Maharashtra, India. Int J Coal Geol 2:371-381

Singh PK, Singh AL, Kumar A, Singh MP (2012) Mixed bacterial consortium as an emerging tool to remove hazardous trace metals from coal. Fuel 102:227-230

Singh AL, Singh PK, Kumar A, Yadav A, Singh MP (2014a) Experimental study on demineralization of coal with Pseudomonas mendocinastrain B6-1 bacteria to obtain clean fuel. Energy Explor Exploit 32(5):831-846

Singh PK, Singh AL, Kumar A, Singh MP (2014b) Petrographic considerations in demineralization of coal with bacteria: a new dimension in understanding the clean coal technology. Energy Explor Exploit 32(4):709-718

Singh AL, Singh PK, Kumar A, Singh MP (2015a) Demineralization of Rajmahal Gondwana coals by bacteria: revelations from X-ray diffraction (XRD) and Fourier transform infra red (FTIR) studies. Energy Explor Exploit 33(5):755-767

Singh AL, Singh PK, Singh MP, Kumar A (2015b) Environmentally sensitive major and trace elements in Indonesian coal and their geochemical significance. Energy Sources Recovery Util Environ Eff 37:1836-1845

Singh PK, Rajak PK, Singh MP, Naik AS, Singh VK, Raju SV, Ojha $S$ (2015c) Environmental geochemistry of selected elements in lignite from Barsingsar and Gurha mines of Rajasthan, Western India. J Geol Soc India 86:23-32

Taylor GH, Teichmüller M, Davis A, Diessel CFK, Littke R, Robert P (1998) Organic petrology. Gebrïder Borntraeger, Berlin, p 704 
Valkovic V (1983) Trace elements in coal, vol 1. CRC Press, Boca Raton, p 210

Vassilev SV, Vassileva CG (1997) Geochemistry of coals, coal ashes and combustion wastes from coal-fired power stations. Fuel Process Technol 51:19-45

Ward CR, Gurba LW, Li Z, Susilawati R (2003) Distribution of inorganic elements in lower-rank coal macerals as indicated by electron microprobe techniques. In: Proceedings of 12th international conference on coal science. Cairns, Queensland, pp 2-86

Zhao CL, Sun YZ, Xiao L, Qin SJ, Wang JX, Duan DJ (2014) The occurrence of barium in Jurassic coal in the Huangling 2 mine, Ordos Basin, northern China. Fuel 128:428-432 